\title{
Improving Participation in the German Search for a Nuclear Waste Repository Site: a WebGIS as a Transdisciplinary Approach to Support Dialogue?
}

\author{
Lucas Schwarz $^{1}$ and Paula Bräuer ${ }^{2}$ \\ ${ }^{1}$ Forschungszentrum für Umweltpolitik, Freie Universität Berlin, Berlin, 14195, Germany \\ ${ }^{2}$ Institut für Informatik, Christian-Albrechts-Universität zu Kiel, Kiel, 24105, Germany
}

Correspondence: Lucas Schwarz (lucas.schwarz@fu-berlin.de)

Published: 10 November 2021

\begin{abstract}
The political and social debate on nuclear energy in Germany has been characterized for many decades by a high potential for conflict and dissatisfaction. In particular, the controversies surrounding the Gorleben salt dome achieved international attention and altered the relationship between the population and political decision makers at the local up to international levels. With the Site Selection Act from 2013 (StandAG, first revision 2017) a new approach was selected in order to find a participative, inclusive and transparent search process for the best possible site of a repository for highly radioactive waste in Germany. In connection with this a self-learning process was proclaimed, based on a white (unprejudiced) map, which aimed to give the general public an active role; however, even the first interim report of the Federal Company for Radioactive Waste Disposal (BGE) and the publication of the multicolored map, in which geologically suitable areas were extensively shown, revealed a massive potential for conflict. Many citizens and activists, who had already protested against the Gorleben salt dome, in this early phase of the process criticized the lack of transparency and opportunities to voice an opinion on possible site regions. In order to counter these criticisms, the possibilities for a web geographic information system (WebGIS) application (interactive map) as an online platform were analyzed (Walkobinger and Tauch, 2018; Brown and Kyttä, 2018). The aim was to virtualy present available geodata (Chwalisz, 2021), which enabled people to contribute to spatial information (geological, superficial) and therefore to achieve an interaction and participation option with respect to the possible site regions. For this, available geodata relevant for the site search process, such as subareas (BGE, 2020), nuclear power stations (active/inactive, research stations etc.), storage facilities (repository, central, intermediate storage etc.), historically relevant sites (sites of protest, uranium-enrichment and preparation plants etc.) and basic data on orientation were used. Based on this, two possibilities for participative interaction were analyzed: (1) the inclusion of spatially located notes that contain own experiences or local knowledge (e.g. reports, concerns, suggestions, own expert opinions) and (2) the initiation of a platform for a spatially located discussion. Against the background of transdisciplinary research, the aim was to evaluate the participative value of this application in an iterative process, in which the research process is supported by an accompanying group from civil society. For this panel we want to present our results from the transdisciplinary research process.

In addition to testing the suitability of such a participation mode, we want to analyze where problems arise and which information is necessary or can lead to conflicts (Griffin, 2020). Finally, we want to gain information on how such participation modes influence the quality of the dialogue and how they contribute to an overall perception of a legally acceptable process (Rzeszewski and Kotus, 2019).
\end{abstract}

Kurzfassung. Die politische und gesellschaftliche Debatte um die Kernenergie in Deutschland ist seit vielen Jahrzehnten durch ein hohes Konflikt- und Unzufriedenheitspotenzial gekennzeichnet. Insbesondere die Kontroversen um den Salzstock Gorleben erlangten internationale Aufmerksamkeit und veränderten das Verhältnis zwischen Bürger*innen und politischen Entscheidungsträger*innen von der lokalen bis zur nationalen Ebene. 
Mit dem Standortauswahlgesetz von 2013 (StandAG, erste Novelle 2017) wurde ein neuer Ansatz gewählt, um einen partizipativen, inklusiven und transparenten Suchprozess nach dem bestmöglichen Standort eines Endlagers für hochradioaktive Abfälle in Deutschland zu finden. In diesem Zusammenhang wurde ein selbstlernender Prozess proklamiert, basierend auf einer weißen (unvoreingenommenen) Landkarte, der den Bürger*innen eine aktive Rolle geben soll. Doch schon der erste Zwischenbericht der Bundesgesellschaft für Endlagerung und die Veröffentlichung der bunten Karte, in der großflächig geologisch geeignete Gebiete ausgewiesen wurden, offenbarten ein massives Konfliktpotenzial. Viele Bürger*innen und Aktivist*innen, die bereits gegen den Salzstock Gorleben protestierten, kritisierten in dieser frühen Phase des Prozesses die mangelnde Transparenz und Mitsprachemöglichkeiten zu in Frage kommenden Standortregionen.

Um dieser Kritik zu begegnen, werden die Möglichkeiten einer WebGIS-Anwendung (interaktive Karte) als Onlineplattform analysiert (Walkobinger and Tauch, 2018; Brown and Kyttä, 2018). Diese soll vorhandene Geodaten virtuell präsentieren (Chwalisz, 2021), es den Menschen ermöglicht, raumbezogene Informationen (geologische, oberflächennahe) beizusteuern und damit eine Interaktions- und Partizipationsmöglichkeit bezüglich der möglichen Standortregionen schaffen. Dazu werden vorhandene, für den Standortsuchprozess relevante Geodaten wie Teilgebiete (BGE, 2020), Kernkraftwerke (aktiv/inaktiv, Forschungsanlagen usw.), Lagerstätten (Standort-, Zentral-, Zwischenlager usw.), historisch relevante Orte (Orte des Protests, Urananreicherungs- und Aufbereitungsanlagen usw.) sowie Basisdaten zur Orientierung genutzt. Darauf aufbauend werden 2 Möglichkeiten zur partizipativen Interaktion analysiert: (1) das Hinzufügen von räumlich verorteten Notizen, die eigene Erfahrungen oder lokales Wissen enthalten (z. B. Berichte, Bedenken, Anregungen, eigene Gutachten) und (2) die Initiierung einer Plattform für eine räumlich verortete Diskussion. Vor dem Hintergrund der transdisziplinären Forschung wollen wir in einem iterativen Prozess den partizipativen Wert dieser Anwendung evaluieren, indem der Forschungsprozess durch eine zivilgesellschaftliche Begleitgruppe unterstützt wird. Für dieses Panel wollen wir unsere bisherigen Ergebnisse aus dem transdisziplinären Forschungsprozess vorstellen.

Neben der Prüfung der Eignung eines solchen Partizipationsmodus wollen wir analysieren, wo Probleme auftauchen und welche Informationen notwendig sind bzw. zu Konflikten führen könnten (Griffin, 2020). Schließlich wollen wir Erkenntnisse darüber gewinnen, wie solche Beteiligungsmodi die Qualität des Dialogs beeinflussen und wie sie zur Gesamtwahrnehmung eines verfahrensgerechten Prozesses beitragen (Rzeszewski and Kotus, 2019).

Financial support. This research has been funded by the Germany Federal Ministry of Economics and Energy, Volkswagen Foundation, Lower Saxony Ministry for Science and Culture (grant number 02E11849A-J).

\section{References}

BGE: Zwischenbericht Teilgebiete gemäß $\S 13$ Stand AG, Peine, 2020.

Brown, G. and Kyttä, M.: Key issues and priorities in participatory mapping: Toward integration or increased specialization? Appl. Geogr., 95, 1-8, https://doi.org/10.1016/j.apgeog.2018.04.002, 2018 .
Chwalisz, C.: The pandemic has pushed citizen panels online, Nature, 589, 171, https://doi.org/10.1038/d41586-021-00046-7, 2021.

Griffin, A. L.: Trustworthy maps, Journal of Spatial Information Science, 20, 5-19, 2020.

Rzeszewski, M. and Kotus, J.: Usability and usefulness of internet mapping platforms in participatory spatial planning, Appl. Geogr., 103, 56-69, https://doi.org/10.1016/j.apgeog.2019.01.001, 2019.

Walkobinger, W. and Tauch, A.: Projekt SuedLink - ein Werkstattbericht, in: AGIT - Journal für Angewandte Geoinformatik, edited by: Strobl, J., Zagel, B., Griesebner, G., and Blaschke, T., Wichmann, Berlin, Offenbach, 123-129, https://doi.org/10.14627/537647015, 2018. 